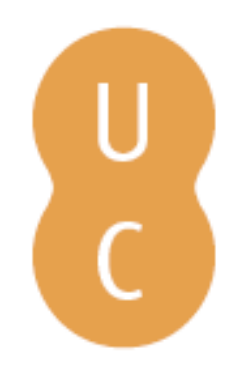

\title{
nommalina
}

\section{O contexto político da extinção da Imprensa da Universidade pelo Estado Novo}

\author{
Autor(es): $\quad$ Torgal, Luís Reis \\ Publicado por: Imprensa da Universidade de Coimbra \\ URL \\ persistente: \\ URI:http://hdl.handle.net/10316.2/32703 \\ DOI: \\ DOI:http://dx.doi.org/10.14195/978-989-26-0423-7_4 \\ Accessed : $\quad$ 26-Apr-2023 15:58:24
}

A navegação consulta e descarregamento dos títulos inseridos nas Bibliotecas Digitais UC Digitalis, UC Pombalina e UC Impactum, pressupõem a aceitação plena e sem reservas dos Termos e Condições de Uso destas Bibliotecas Digitais, disponíveis em https://digitalis.uc.pt/pt-pt/termos.

Conforme exposto nos referidos Termos e Condições de Uso, o descarregamento de títulos de acesso restrito requer uma licença válida de autorização devendo o utilizador aceder ao(s) documento(s) a partir de um endereço de IP da instituição detentora da supramencionada licença.

Ao utilizador é apenas permitido o descarregamento para uso pessoal, pelo que o emprego do(s) título(s) descarregado(s) para outro fim, designadamente comercial, carece de autorização do respetivo autor ou editor da obra.

Na medida em que todas as obras da UC Digitalis se encontram protegidas pelo Código do Direito de Autor e Direitos Conexos e demais legislação aplicável, toda a cópia, parcial ou total, deste documento, nos casos em que é legalmente admitida, deverá conter ou fazer-se acompanhar por este aviso. 
FERNANDO TAVEIRA DA FONSECA • JOSÉ ANTUNES IRENE VAQUINHAS • ISABEL NOBRE VARGUES • LUIS REIS TORGAL FERNANDO J. REGATEIRO

Imprensa da Universidade de Coimbra Uma história dentro da História

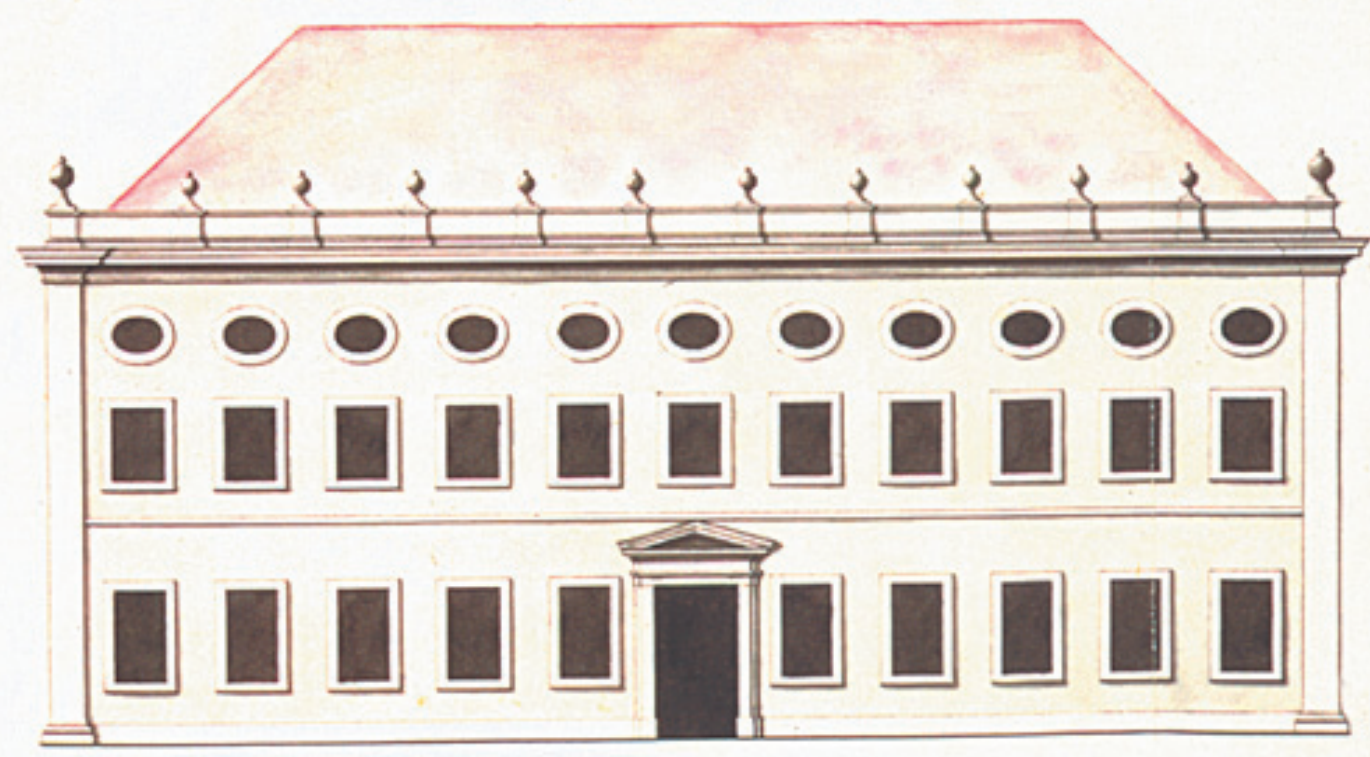

KLPVACAO GROMVTRICA.

IMRENRA DA UNAVKRSIDADK DK COHBARA. 
(Página deixada propositadamente em branco) 


\title{
Imprensa da Universidade de Coimbra Uma história dentro da História
}

\author{
Fernando Taveira da Fonseca \\ José Antunes \\ Irene Vaquinhas \\ Isabel Nobre Vargues \\ Luís Reis Torgal \\ Fernando J. Regateiro
}

Coimbra - Imprensa da Universidade 
COORDENAÇÃO EDITORIAL

Imprensa da Universidade de Coimbra

\title{
CONCEPÇĂO GRÁFICA \\ António Barros
}

\author{
INFOGRAFIA
}

Paula Isabel jorge

Estimulus [design] • Coimbra

EXECUÇĀO GRÁFICA

Imprensa de Coimbra, Lda.

Couraça dos Apóstolos. 126

3000-372 Coimbra

IlUSTRACÁO DA CAPA

Guilherme Elsden. alçado principal da Imprensa

(Riscos dos Obras do Unversidade de Coumbro.

prop. part. foto: José Pedro Aboim Borges)

ISBN

$972 \cdot 8704 \cdot 02 \cdot X$

DEPOSITO LEGAL

$171893 / 01$

(C) NOVEMBRO 200I. IMPRENSA DA UNIVERSIDADE DE COIMBRA 


\section{O Contexto Político}

\section{da Extinção da Imprensa da Universidade pelo Estado Novo}

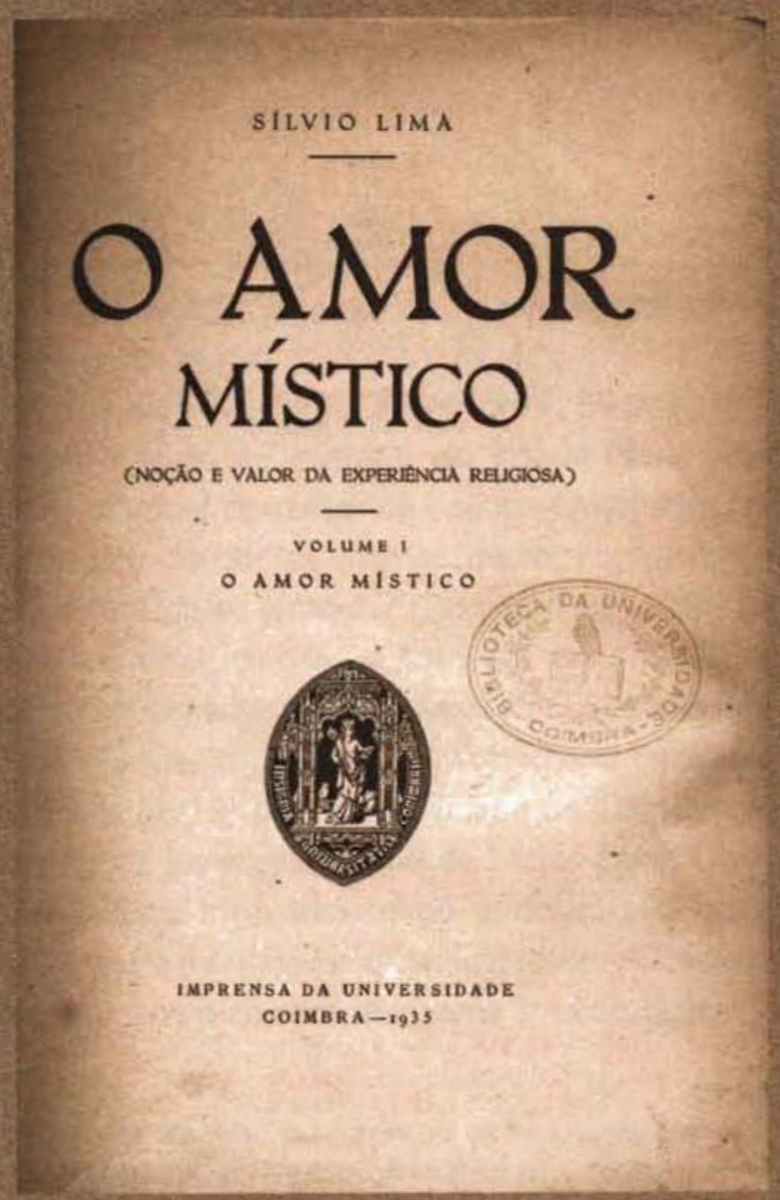


Lima. Silvio - O Amor Mistico: noçōo e valor da experiéncio religiosa.

Coimbra, Imprensa da Universidade, 1935. 


\section{LUIS REIS TORGAL.}

\section{O CONTEXTO POLÍTICO DA EXTINÇÃO \\ DA IMPRENSA DA UNIVERSIDADE \\ PELO ESTADO NOVO}

\section{Introdução}

Falar da extinção da Imprensa da Universidade, secular instituição de criação pombalina, cujo último administrador (de 1921 a 1934/35) foi o republicano histórico, assumidamente demoliberal, Joaquim de Carvalho, é falar de todo o movimento de controlo do Estado Novo sobre as várias instituiçōes e sobre as várias correntes de opinião. $\mathrm{O}$ objectivo era criar uma só ideologia, no âmbito do que se chamou, de forma eufemística, a "União Nacional". Daí que terá de se entender a extinção da Imprensa como uma forma de neutralizar uma instituição com grande produção editorial e impressora, que eventualmente poderia fugir da fiscalização do Estado.

Joaquim de Carvalho (1892-1958)(1), bacharel formado em Direito (1914) e em Filosofia (1916) pela Universidade de Coimbra, foi nomeado assistente provisório da jovem Faculdade de Letras dessa Universidade no mesmo ano da sua última formatura, tendo-se doutorado, em 1917. com a tese António de Gouveia e o Aristotelismo da Renascença $a^{(2)}$. Ensinou, sobretudo, na área de Filosofia e, complementarmente, na área de Educação, dado que

(1). Sobre Joaquim de Carvalho, para além de vários estudos que foram escritos em sua homenagem (cfr. bibliografia no texto de Jorge Peixoto à frente referido). vide Manuel Augusto Rodrigues (dir.). Memorio Professorum Universitatis Conimbrigensis. 1772-1937. Coimbra, Arquivo da Universidade de Coimbra, 1972. pp. 70 e 333, e Jorge Peixoto, "A Imprensa da Universidade e a acçāo de Joaquim de Carvalho", in Arquivo de História e Bibliogrofio. 1923-1926, vol. I. Lisboa, Imprensa Nacional - Casa da Moeda, 1976. pp. XIII-LXXV.

(2). António de Gouveia e o Aristotelismo da Renascença. Vol. I António de Gouveio e Pedro Romo. Coimbra, França Amado, 1916. 
prestou também serviço na Escola Normal Superior, anexa às Faculdades de Letras e de Ciências, criada em 1911 e extinta em 1930. Como bom republicano, pertenceu a organizações características do movimento, nomeadamente a Universidade Livre, criada em 1925, e a Maçonaria, tendo sido iniciado em 1912 na loja "A Revolta" com o nome simbólico de Guyau('(3), filósofo francês da segunda metadade do século XIX, defensor de uma moral arreligiosa e sem sanções, baseada no princípio da solidariedade, que, sintomaticamente, foi objecto de uma tese de licenciatura do seu correligionário, bastante mais novo, Sívio Lima ${ }^{(4)}$. Mas, o republicanismo de Joaquim de Carvalho não o impediu de defender a Universidade e a Faculdade a que pertencia, da tentativa do Ministro da Instrução Pública Leonardo Coimbra - em 1919, no contexto da reaç̧ão à revolta monárquica do Norte e da suspensão de quatro lentes da Faculdade de Direito, entre eles o jovem professor António de Oliveira Salazar — de "desanexar" a Faculdade de Letras de Coimbra, "anexando-a" à Universidade do Porto(5). Talvez tenha sido afinal a sua incontestada posição de cidadania e, concretamente, a sua "resposta" que originou o recuo do Ministro da Instrução. Apesar de ter fundado a faculdade na cidade do Porto, a qual teve a duração de cerca de dez anos (voltou a ser restaurada nos anos sessenta), acabou por não executar a medida de extinção da faculdade em Coimbra.

Algo de idêntico não sucedeu, porém, no Estado Novo, que levou a efeito, na lei e na prática, a extinção da Imprensa da Universidade. removendo todo o material tipográfico para a Imprensa Nacional em Lisboa, passando à situação de "adidos" os empregados de nomeação vitalícia, fazendo cessar as funçōes em comissão de serviço àqueles que se encontravam em tal posição e dispensando os assalariados( ${ }^{(6)}$.

(ग). Cfr. A. H. Oliveira Marques, Dicionário de Maçonaria Portuguesa, Lisboa, Editorial Delta, 1986, vol, I, col. 286.

(4). Ensaio sobre a Ética de Guyau nas suas relações com a crise moral contemporônea, Coimbra, 1927.

(5). Cfr. A minha resposta ao último considerando do decreto que desanexou a Foculdade de Letras da Universidode de Coimbra, Coimbra, França Amado, 1919. Ver também A Faculdode de Letros do Universidade de Coimbra ao Pois. Coimbra. França Amado, 1919.

(6). Vide artigo $38 .^{\circ}$ do Decreto-Lei n..$^{\circ} 24$ 124, de 30 de Junho de 1934, que ditou e extinção da Imprensa da Universidade, e a regulamentaçẫo dessa extinçăo no Decreto-Lei n. 24440 , de 29 de Agosto de 1934, sobretudo artigos $2 .^{\circ}$ e $3 .^{\circ}$. 
O primeiro estudo sobre o tema surgiu pouco depois de 25 de Abril de 1974 pela pena de Jorge Peixoto, que quis assim render homenagem e prestar justiça a Joaquim de Carvalho(7). Mais de vinte anos depois tornámos ao tema, não de uma forma especializada mas apenas no contexto do nosso estudo, com outra perspectiva, das relações entre a Universidade e $\circ$ Estado Novo ${ }^{(8)}$ Agora, perante o convite que nos foi formulado para escrever um texto sobre a questão, pareceu-nos mais apropriado voltar a essa obra que publicámos em 1999(9). O contexto político da época - finais dos anos vinte e inícios dos anos trinta do século $X X$. de passagem da Ditadura Militar para o Estado Novo - explicam, mais que meros factos ou conjecturas, a extinção da Imprensa da Universidade e outras medidas repressivas que então ocorreram.

\section{Os debates políticos na "Universidade" e na "Academia"}

Durante a sessão solene de abertura da Universidade ocorrida em 16 de Outubro de 1926, perante o Presidente do Ministério, General Oscar Carmona, o reitor da Universidade de Coimbra e professor da Faculdade de Medicina, Fernando de Almeida Ribeiro - eleito em 21 de Junho, pouco depois do "28 de Maio", que, curiosamente, mas dentro de uma certa lógica interna, repusera, aliás apenas episodicamente, o direito de a Universidade eleger os seus reitores, voltando às medidas do início da República e. sobretudo, da "República Nova" de Sidónio Pais(10) - afirmava:

(7). "A Imprensa da Universidade de Coimbra e acção de Joaquim de Carvalho", in ob. cit.

(8). A Universidade e o Estado Novo. O coso de Coimbro. 1926-1961, Coimbra. Minerva. 1999.

(9). O texto que a seguir se apresenta é, pois, essencialmente. com algumas pequenas alteraçōes. o texto do capítulo II do nosso livro. já citado. A Universidade e o Estodo Novo.

(10). Cfr. Decreto n. 11721 , de 12 de Junho de 1926, que revogou o artigo $1 .^{\circ}$ da lei n. ${ }^{\circ} 861$, de 27 de Agosto de 1919, quanto à nomeação dos reitores das Universidades (art. $\left.1^{\circ}\right)$, repondo assim a autonomia pedagógica que lhes fora concedida pela Constituiçẫo Universitária, de 19 de Abril de 1911, ampliada pelo Estatuto Universitáno, de 6 de Junho de 1918. Dizia o art. $2{ }^{\circ}$ do referido decreto: "No prazo máximo de quinze dias. a contar da publicaçăo deste decreto, reunirão as assembleias gerais das universidades para a eleição 
"No actual Governo, como acontecera no que imediatamente o precedeu, encontra-se uma representação honrosa desta Universidade. E nos mais anteriores governos republicanos, com as suas diversas e sucessivas modalidades, igualmente Mestres e graduados desta Escola sempre procuraram bem servir Portugal e a República. Com as suas diversas modalidades, eu dizia... Porque, na Universidade, estas também se encontram: nos professores republicanos, como naqueles que antigamente serviram 0 Portugal monárquico, não há apenas um único modelo de pensar. $\mathrm{E}$, desde os mais avançados ideais, até ao modo de ver conservador daqueles que julgam esses ideais desproveitosos, na Universidade de Coimbra cabem todas as opiniões que, por caminhos diferentes, só têm por fim servir o Estudo, a Ciência e Portugal. Porque a tolerância mútua e o respeito pela liberdade alheia e pelas opiniões que não são as próprias garantem pacificamente a todos, da maneira mais eficaz e proveitosa, a mais respeitável e, felizmente, também, a mais incoercivel de todas as liberdades, que é a do pensamento!"(11).

Nestas palavras de Almeida Ribeiro, que em breve pediria a demissão, menos por razōes políticas do que por motivos corporativos ${ }^{(12)}$, está esboçado o retrato da situação da Universidade durante os anos da Ditadura e até. em alguns aspectos, durante os primeiros anos do Estado

dos reitores e vice-reitores [...]": O decreto n." 12 426, de 2 de Outubro de 1926, que publicou o novo "Estatuto da Instrução Universitária", regulou da seguinte forma a eleição dos reitores das Universidades de Coimbra, Lisboa e Porto: "À Assembleia Geral da Universidade compete a eleição do Reitor e Vice-Reitor. A eleição será comunicada ao Governo em lista tríplice para cada um dos cargos, para os quais este nomeará respectivamente um dos eleitos" (cap. I. art. 5. .). Deve aqui salientar-se que o último reitor da Universidade de Coimbra a ser eleito antes do "28 de Maio". no periodo sidonista. fora Mendes dos Remédios (1918-1919), que foi Ministro da Instrução Pública em 1926 e que

96 assinou o primeiro decreto referido. constituindo. com Salazar e Manuel Rodrigues, a célebre troika de Coimbra que pouco depois da "Revolução Nacional" ocupou por breves dias (quanto a Salazar e a Mendes dos Remédios) lugares de Governo.

(11). "Discurso pronunciado na Abertura Solene da Universidade em 16 de Outubro de 1926", in Revisto da Universidade de Coimbra, vol. X. Coimbra, Imprensa da Universidade, 1927. p. 574 .

(12). Cfr. o texto impresso Oficio oo Senado da Universidade de Coimbra. Coimbra, 1927. Neste ofício. datado de 7 de Maio de 1927. Almeida Ribeiro explica que pedira a demissão (o que ocorreu em Março desse ano) devido à publicaçăo do decreto-lei n. ${ }^{\circ} 13273$, de 10 
Novo. Não há, como se vê, nenhuma posição contrária à Primeira República, que acabara de cair, e há uma clara afirmação de pluralismo ideológico.

Meses antes do "28 de Maio", que fora por uns aclamado e por outros apupado, dera-se uma greve geral dos estudantes por motivos académicoprofissionais, que fora liderada pelos alunos da Faculdade de Letras ${ }^{(13)}$, e em Abril o grupo "Seara Nova" organizara em Coimbra um ciclo de conferências, a que estivera ligado, entre outros republicanos, Joaquim de Carvalho(14). Durante a Ditadura vai subsistir no país e na Universidade um ambiente de instabilidade, originado no caso desta última por lutas de carácter essencialmente estudantil, que teriam no entanto atrás de si

de Março de 1927, que condenava o escrutínio secreto no caso de nomeaçăo de segundos assistentes e da sua recondução e também no caso da recondução de primeiros assistentes. substituindo-o por voto aberto. Esta lei era considerada como atentatória da autonomia universitária e visava. segundo o ex-Reitor. a Faculdade de Medicina. Por essa altura, com efeito, surgiram conflitos graves nessa Faculdade relativamente à recondução de assistentes - nomeadamente Cid de Oliveira, proposto por Bissaya Barreto, o qual terá estado no centro da questäo, tendo em conta que as quezilias que manteve com os colegas e viceversa foram constantes (ver o trabalho, não publicado, de Ana Maria Mendes, Subsídios paro a histório das relaçōes entre Bissaya Barreto e a Foculdade de MedicinalUniversidade. Coimbra. 1993. e Jorge Pais de Sousa, Bissaya Barreto. Ordem e Progresso. Coimbra, Minerva. 1999) que ecoaram nas páginas dos jornais, originaram polémicas entre professores nos órgãos universitários e provocaram a intervençāo de estudantes (ver A. J. Soares. Saudades de Coimbra, vol. 11, 1917-1933. Coimbra, Almedina, 1985. notícias dos anos 1926 e 1927. Não se designam as páginas porque elas não são numeradas).

(13). Cfr. Ferreira Gomes, ob. cit. pp. 435 ss. Pedia-se. por exemplo, para alargar os quadros do magistério liceal e os estudantes de Letras e de Direito clamavam contra as facilidades concedidas aos formados pelo Instituto Superior de Comércio, quer pelo facto de poderem reger certas cadeiras do ensino liceal. quer porque podiam concorrer à carreira diplomática.

(14). Ver A. J. Soares. ob. at. vol. II. noticias de Janeiro. Abril e Maio de 1926. Muitas das informaçōes que a seguir se referem foram colhidas no rico memorial apresentado por este autor. Por isso, abster-nos-emos de o citar. Relativamente às conferências da Searo Novo. segundo a informação de A. f. Soares, realizaram-se no Teatro Sousa Bastos, tendo vindo a Coimbra António Sérgio. Câmara Reis, Jaime Cortesăo. Ezequiel de Campos e Sarmento de Beires. Também proferiu uma conferência o quintanista de Direito Mário de Castro. Jorge Peixoto dá-nos informaçōes mais completas, nomeadamente quanto à participação de Joaquim de Carvalho neste evento. Na verdade, por razōes de saúde, não pôde presidır à sessão, realizada em 26 de Abril de 1926, em que falaram Sérgio e Sarmento de Beires, tendo por isso de ser substituido porVitorino Nemésio. Já no dia 25. por altura de um almoço de confratemizaçāo. Joaquim de Carvalho não pudera estar presente, tendo dirigido a Vitorino 
motivaçōes políticas e que provocaram desenvolvimentos políticos, como aquelas que resultaram de reformas do ensino superior, as quais regulamentavam os exames, criavam uma prova de admissão à Universidade, aumentavam as propinas, extinguiam certas instituiçōes (como, em Coimbra, a Faculdade de Farmácia e a Escola Normal Superior, ao passo que no Porto se extinguia a Faculdade de Letras e em Lisboa a Faculdade de Direito, medida esta que, no entanto, não chegou a ser executada(15)) e procuravam alterar a estrutura das Faculdades ${ }^{(16)}$. Mas, para além dessas polémicas, que originaram constantes avanços e recuos na política de Instrução Pública(17). desenrolaram-se outras de tipo fundamentalmente político, que opunham entre si "republicanos" e "integralistas" (para empregar as expressōes gerais e simplistas usadas no tempo).

Por parte dos republicanos as lutas e as conspirações eram naturalmente lideradas pelo Centro Republicano Académico, reorganizado em 1925, na fase agónica da Primeira República, que mantinha ainda um estatuto de legalidade,

Nemésio uma carta (transcrita por jorge Peixoto) na qual pedia ao seu amigo para, em seu nome. saudar "os arautos da renovaçāo da República" (cfr. texto citado in ob. cit., pp. XXIV$X(X)$.

(15). Cfr. Decreto n..$^{\circ} 15$ 365. de 12 de Abril de 1928. A Faculdade de Farmácia de Coimbra, que fora promovida da categoria de Escola a Faculdade em 1921. foi extinta em 1928, mas acabou por ser restaurada. outra vez como Escola. em 1932. A Escola Normal Superior extinta pelo mesmo decreto, acabou por dar lugar, em 1930, à secção de Ciências Pedagógicas nas Faculdades de Letras. Sobre estes temas, para o caso de Coimbra, ver João Rui Pita, "Breve história da Faculdade de Farmácia da Universidade de Coimbra. Uma perspectiva cientifico-profissional", in Munda, n. 24. Coimbra. 1992. pp. 3-16. A. Pinho Brojo, Maria de Lourdes Rebelo e João Rui Pita (org). Formácia. Ciência e Universidade. A fundoção do Faculdade de Farmócia em 1921. Coimbra, Minerva. 2000, e a obra de Joaquim Ferreira Gomes. A Escola Normal Superior da Universidade de Coimbra (1911-1930). Lisboa, Instituto de Inovaçăo Educacional. 1989.

(16). Ver vários documentos sobre a luta académica desencadeada em Coimbra. em 98 Lisboa e no Porto, in Os estudantes no regime foscisto, Lisboa, Presidência do Conselho de Ministros - Comissão do Livro Negro sobre o Regime Fascista, 1983. Chama-se particularmente a atenção para o documento "Carta Aberta dos Estudantes das Universidades Portuguezas ao Ex.mo Sr. Ministro da Instrução", de 24 de Maio de 1928, p. 110 s5., e para o depoimento de Mário Cal Brandão, "A Academia de Coimbra e a ditadura", p. 152 ss.

(17). É impressionante a quantidade de legislaçāo que nessa altura se produziu, verificando-se que muitas das leis vêm exactamente contradizer as antenores, o que comprova a falta de uma política definıda quanto à Instrução Pública. Agradeço aos meus antigos alunos 
com o apoio de lojas maçónicas, das quais se destacava "A Revolta", com longa tradição revolucionária atrás de $\mathrm{si}^{(18)}$. Jornais, provindos do C.R.A. ou de independentes republicanos, iam saindo por um curto espaço de tempo, trazendo a público esse ambiente de luta. É isso que se passa, por exemplo, como periódico Gente Nova (9 de Abril de 1927 a 18 de Maio de 1928), do C.R.A. que tinha como directorVitorino Nemésio e onde escreveram também Carlos Cal Brandão, Silvio Lima e Paulo Quintela, ao que sucedeu o Mundo Novo (4 de Fevereiro a 11 de Março de 1931), também promovido pelo C.R.A., e dirigido por Fernando Miranda e Álvaro Monteiro, e com o jornal republicano independente Voz do Povo ( 15 de Novembro de 1928 a 15 de Março de 1929), que se apresenta como um jornal colaborado por estudantes, mas não, de forma classista, um "jornal de estudantes"(19).

Os temas tratados nestes periódicos efémeros sāo elucidativos das lutas que se travavam, no seio da Universidade e fora dela. Para além das polémicas com as autoridades universitárias, a que nos iremos referir. poderemos destacar, pelo seu significado, outras temáticas interessantes. Uma das posições assumidas foi a defesa de uma Universidade única, que se situava na tradição napoleónica, e que era uma forma de defender a ideia de uma Universidade, a "Universidade Portuguesa", adequada aos princípios republicanos, com repúdio das concepçōes entendidas como sobrevivências do passado, vigentes nas três universidades existentes ${ }^{(20)}$. A "questão da capela", ou seja, o debate acerca do problema de saber se a capela da Universidade deveria ou não abrir ao culto, tal como defendiam os estudantes católicos e integralistas, foi também objecto de discussão. Evidentemente que os jornais republicanos optavam pela defesa da não abertura, com fundamento na ideia laicista de que reabrir a capela ao culto

António Farinha Alves e Luciano Mendes o esgotante trabalho que tiveram para constituir uma colecçăo de legislação sobre o tema que, se foi utilizada neste trabalho e em outros que foram realizados, está longe de ter sido analisada de forma sistemática.

(18). Cfr. Os estudontes no regime foscisto, o depoimento de M. Cal Brandão. pp. 153-154.

(19). Sobre os jornais desta época, ver A. Carneiro da Silva, Jornois e revistos do distrito de Combro, Coimbra. Biblioteca Municipal. Separata do Arquivo Coimbröo, 9-10, 1947. Aproveitámos, em certa medida, os estudos levados a efeito neste campo pela então aluna Dina de Fátima Pires, autora do trabalho escolar, não publicado, Conflitos Acodémicos no Universidade de Coimbro. Jornalismo estudantil.

(20). Ver o artigo "Universidade Portuguesa", in Voz do Povo. n. ' 2. 1.12.1928. 
seria fazer voltar a Universidade ao seu carácter confessional(21). As posições antipraxísticas também aparecem com frequência, na boa tradição liberal e republicana, procurando-se assim lutar contra costumes entendidos como obsoletos(22). Mas também, ultrapassando os meros assuntos académicos. estes jornais tomavam naturalmente posiçōes politicas e sociais mais amplas. Por exemplo, defendiam o feminismo (23), atacavam o fascismo e a Carto del Lavoro(24) ou mesmo o estalinismo(25). E. curiosamente, em tempo de hesitação quanto ao futuro político de Portugal e à posição a assumir pelo seu futuro líder, defende-se o cooperativismo, criticando-se o corporativismo e utilizando para tal o próprio pensamento de Salazar(26).

A colaboração de estudantes, e até de alguns professores, em tentativas de golpes e em manifestações contra a Ditadura ou pelo menos de afirmação de fé republicana, sucediam-se. Verificaram-se movimentações académicas de apoio ao golpe falhado de 7 de Fevereiro de 1927, ao qual se seguiram outras tentativas igualmente goradas; ocorreram contramanifestações relativamente ao movimento de apoio ao general Ivens Ferraz, Ministro do Comércio e interinamente Ministro das Finanças, na sua passagem pela estação de Coimbra, vindo de Paris, onde recusara as condições do empréstimo que the haviam sido impostas pela Sociedade das Nações, por pressão da Liga de Defesa da República, formada pelos exilados políticos republicanos ${ }^{(27)}$, como também se deram tentativas de boicote a conferências de cunho nacionalista. Escreveram-se vários manifestos contra a Ditadura, que originaram inquéritos e detenções no seio dos estudantes republicanos. Com a queda de Miguel Primo de Rivera, em Espanha, houve manifestaçōes de apoio à República espanhola, assim como a "Revolta da Madeira", ocorrida em 1931, haveria de originar, após uma manifestação no Largo da Portagem, algumas prisões. Sucedem-se as celebrações do 31 de Janeiro e em Maio de 1933 os "gravatas vermelhas" (assim eram conhecidos

(21). Ver. por exemplo. Gente Novo. n.os 8 e 9. A polémica foi travada. sobretudo, com o jornal "integralista" Ideia Nova, a que à frente nos iremos referir.

(22). Ver, por exemplo, o artigo "Praxes académicas", in Voz do Povo, n. ${ }^{\circ}$ 2. 1.12.1928.

(23). Ver "O Feminismo", in A Voz do Povo. n." 3. 15.12.1928.

(24). Cfr. Gente Novo. n. 16. 30.4.1928, "Três notas à margem do Fáscio".

(25). Cfr. Voz do Povo. n. ${ }^{\circ}$ 2. I.12.1928.

(26). Cfr. "Corporação e Cooperação", in Voz do Povo, n. ${ }^{\circ} 4$. 23.1.1929.

(27). Depoimento de M. Cal Brandão, in ob. cit, pp. 154-156. 
os estudantes republicanos que, quando trajavam capa e batina, substituíam a gravata por uma roseta vermelha na lapela) promovem um cortejo de homenagem ao túmulo de josé Falcão.

Mas, entretanto, desenvolviam-se acções a favor da Ditadura, ou de oposição à República e aos republicanos, por parte dos "integralistas", ou seja, falamos agora, grosso modo, em sentido amplo, de monárquicos, republicanos desiludidos e de sentido nacionalista e autoritário, católicos tradicionalistas e até alguns fascistas assumidos, que se reuniriam à volta do partido nacionalsindicalista (os "camisas azuis") (28). Assim, logo em Fevereiro de 1927, ocorre uma manifestação de apoio ao Governo, a que se sucedeu uma manifestação de apoio ao "28 de Maio", no largo de Sanção (ou Praça 8 de Maio), frente ao mosteiro e igreja de Santa Cruz, e à qual se sucederão outras a pretextos diversos. Ocorrem contramanifestações a actos dinamizados pelos estudantes republicanos e tinge-se de negro a lápide comemorativa da República, que se encontrava cravada no edifício da Universidade. A Associação Académica de Coimbra, enquanto dirigida por "integralistas", o que sucede até 1928, convida estadistas da Ditadura e promove conferências de cunho nacionalista, como aconteceu no dia I de Dezembro de 1927 em que Cabral Moncada, professor da Faculdade de Direito, proferiu uma célebre conferência sobre $1640 \mathrm{com}$ intenções persuasivas de apoio ao novo regime saído do "28 de Maio"(29). Sucedem-se também os jornais "monárquicos integralistas", sem dúvida os mais militantes, como /deia Nova (8 de Dezembro de 1927 a 31 de Março de 1928). Acção Nacional (24 de Janeiro a 21 de Março de 1929) ou Vanguardo ( 25 de Fevereiro de 1928 a 24 de Março de 1929), que, para além de intervirem nas lutas académicas, tomam posições políticas de princípio e inserem artigos de escritores e políticos que não pertenciam à Academia.

Ideia Nova, cujos responsáveis eram os estudantes Bento Caldas e José Adriano Pinto Coelho, liderou as lutas contra as ideias republicanas de Gente Novo, nomeadamente em relação à citada "questão da capela", tomando posiçōes muito duras e de carácter pessoal conta Vitorino Nemésio. Acção Nacional, dirigido por Alberto Pires de Lima, citando Sardinha, Cabral

(28). Sobre o tema, veja-se a obra de António da Costa Pinto. Os comisos azuis. Ideologia, elites e movimentos foscistos em Portugal. 19/4-1945. Lisboa. Editorial Estampa. 1994.

(29). Vide Cabral Moncada, "I640... Restauraçăo do Pensamento Político Português", in Boletim da Foculdade de Direito de Coimbra, vol. X. Coimbra, 1929. pp. 447-477. 
Moncada e João Ameal, defende como programa o "Nacionalismo Integral Português"(30), Invoca-se Nietzsche, admira-se Paul Valéry ou Proust, Manuel Ribeiro ou Antero de Figueiredo, e aconselha-se a leitura do Marquês de Penalva ou de Gama e Castro, de António Sardinha ou de Hipólito Raposo, de La Tour du Pin, de Barrès ou de Charles Maurras. Surgem textos literários de António Correia de Oliveira ou de Augusto Gil, artigos de Alfredo Pimenta ou de Fernando de Campos. Há lugar também para louvar Mussolini e a sua política religiosa - "o primeiro homem de Estado do seu tempo"(31).

Vanguarda foi o órgão da junta Escolar do Integralismo Lusitano, dirigido por Leão Ramos Ascensão e, depois, por Abrantes Tavares. Nele não faltam elogios a Mussolini, o cântico da Giovinnezo, o anti-semitismo(32), ou, noutra frequência, o elogio a Salazar, a Cerejeira e ao Padre Mateo Crawley. Referindo-se a uma conferência realizada no Salão São Tomás de Aquino do Seminário Diocesano por esse "grande apóstolo do nosso tempo", pode ler-se esta conclusão:

"Se como demonstra Bardieff num livro notável, estamos a braços com as derradeiras e insensatas consequências da ética pagã, restaurada pelo Humanismo do século XVl, e desta angustiosa confusão os espíritos se levantarão redimidos para uma nova Idade Média - em que o homem reconquistará toda a profunda espiritualidade da sua natureza - o Padre Mateo pertence incontestavelmente a essa nova era."(33)

Entretanto, o "Centro de Estudos Nacionalistas" promove em Janeiro de 1931 uma conferência que foi proferida por Luís de Almeida Braga no Teatro Avenida, com o sugestivo título "Do Estado antigo ao Estado Novo"; ao poeta nacionalista António Correia de Oliveira é atribuído, no ano anterior, a honra de "perpétuo quintanista de Letras", com a crítica mordaz da Intelligentsia literária de Coimbra, nomeadamente do grupo da Presença. Ele será afinal o poeta oficial do regime, como João Ameal foi o historiador. Vale a pena

(30). Cfr. Acçâo Nocional, n. ${ }^{\circ}$ I. 24.6.1929.

(31). Cfr. "A política religiosa de Mussolini", in jornol cit. n. ${ }^{\circ} 8,21.3 .1929$.

(32). Cfr. Vanguarda, respectivamente, n. ${ }^{\circ} 8,5.5 .1928$, "Italia rinnovato"; n. ${ }^{\circ}$ 14, 2.2.1929, "Os estudantes e a politica"; e n. ${ }^{\circ}$ 16. 25.2.1929. "Breves considerações sobre os judeus".

(33), jornal cit. n. ${ }^{\circ}$ 2. 3.3.1928. 
aproveitarmos o ensejo para, neste momento, rumarmos até ao Brasil e até 1937 e ouvirmos alguns versos do poema Pótria nossa, Pátria vossa, então recitados pelo poeta no Gabinete Português de Leitura do Rio. Depois de falar de Nossa Senhora, que desceu em Fátima e a tornou o "Mirante do Milagre Português", declamou, referindo-se a Cerejeira e a Salazar:

"E Deus que em Portugal (qual é memória...)

Sempre acabou o que Ela principia,

Consigo disse então:

- "Que falta aos Portugueses depois disto?

Um sagrado doutor em Jesus Cristo,

E um Doutor em Nação."

E. logo, entre o mais povo os escolheu.

Depois de os ter formado

Para o momento eterno e destinado,

Noutra Coimbra que há de haver no Céu."(34)

Poucos comentários haverá a fazer a esta visão de providencialismo político de António Coreia de Oliveira, que constituía o poeta emblemático dos variados grupos "integralistas". O próprio jornal Revolução, dos nacional-sindicalistas, publicava a sua fotografia na edição de 4 de Junho de 1932.

Em 21 de Maio de 1933 os "camisas azuis" promoviam uma concentração na Quinta da Várzea, próximo das Lajes, nos arredores de Coimbra, à qual o seu diário. publicado em Lisboa, deu grande destaque em números sucessivos. No banquete então realizado, foi homenageado Eusébio Tamagnini, professor da Faculdade de Ciências, o líder do movimento em Coimbra, tendo discursado, entre muitos outros, para além de Rolão Preto. os professores da Faculdade de Direito Luís Cabral Moncada, também seu apoiante, e Mário de Figueiredo que, não se afirmando nacional-sindicalista, quis estar presente. (35)

(34). Pótrio nossa, Pátria vossa. Saudaçāo ao Brasil. (Real Gabinete Português de Leitura: Sessão Solene de 10 de Junho de 1937), Rio de Janeiro, Ediçōes Brasilusa, 1937. p. 29.

(35). Ver Revoluçōo, 20.5.1933 e números seguintes. 
É afinal neste contexto de emoções nacionalistas de variada tendência que se verifica a espectacular "conversão" de Bissaya Barreto, professor da Faculdade de Medicina, republicano do primeiro momento, que militara na Carbonária e na loja "A Revolta", que participara nas greves académicas do final da Monarquia, que fora deputado às Constituintes e membro do Partido Evolucionista de António José de Almeida. Mas, diga-se também que essa conversão não foi paćfica, provocando alguns conflitos internos entre as organizações que se haviam formado de apoio à Ditadura.

Com efeito, Bissaya Barreto que, independentemente da viragem das suas ideias políticas, se tornara amigo de Salazar por ter sido médico de sua mãe, D. Maria do Resgate, afirmou a sua adesão ao regime, já a dar passos fundamentais para o Estado Novo, por altura da visita a Coimbra do Ministro do Interior, Dr. Mário Pais de Sousa, praticamente conterrâneo de Salazar, seu antigo aluno e irmão de um seu cunhado. Dirigindo-se ao Ministro, considera que ele representa um símbolo de "formação de uma valorosa corrente" que - no seu dizer - "nos há-de levar ao Estado Novo", ao "Estado Novo Republicano", que solicitaria a "colaboraçāo de todos os bons Portugueses, que, despidos da sua ideologia e dos seus autorismos, vejam na República Portuguesa a única garantia de salvação do país nesta época de incerteza".

Era, assim, neste sentido de "união nacional", de "reconciliação da Familia Portuguesa", com um apelo expresso aos "republicanos conservadores" - que teriam de abandonar a sua ideologia política." "inviável nos tempos que passam" -. de uma concepção de "Estado Novo Republicano", liderado pelo "Grande Português, grande estadista e grande coração", o Dr. Oliveira Salazar, que se operara a conversão do já célebre professor de Coimbra. Realizava-se num "ambiente de consenso", com a presença de velhos republicanos, como Albino dos Reis, que militara na União Liberal Republicana, liderada por Cunha Leal, e que era entāo Governador Civil de Coimbra.(36)

Fora uma espectacular conversão. Normalmente os lentes e Coimbra que 104 apoiaram Salazar situavam-se no sector católico ou mesmo nacional-sindicalista. Por isso, e devido a contenciosos diversos havidos por Bissaya Barreto na Universidade e sobretudo na Faculdade de Medicina, a conversāo soava a

(36). Cfr. Diório de Coimbro. 21.12.1931. Sobre Bissaya Barreto, vide Jorge Pais de Sousa, Bissaya Barreto. Ordem e Progresso, Coimbra, Minerva. 1999. 
escândalo.A ligação do médico republicano á Uniāo Nacional que se the seguiu iria gerar uma ruptura no partido do Governo em formação. Mas Bissaya manter-se-á a frente dos destinos da U.N., vindo a ser Presidente da Delegação Distrital e, no I Congresso, em 1934, já com o Estado Novo institucionalizado, - Presidente da 5a. Sub-Secção, "Saúde e Assistência".

Todavia, nos meios estudantis eram os republicanos que venciam as lutas institucionais. Haja em vista $\circ$ facto de a Presidência da Associação Académica ter sido por eles ocupada em anos sucessivos, até que o Estado Novo, em 1936, pondo termo a essa liderança e também ao processo eleitoral, nomeou uma comissão administrativa, e o facto de os republicanos serem geralmente eleitos para representantes ao Senado e à Assembleia da Universidade, situação que se extinguiu também nesse mesmo ano, com a suspensão da representação estudantil nesses órgãos.

A luta dos estudantes republicanos, nestes tempos conturbados e, ainda assim, apesar da forte repressão, com algum pluralismo e liberdade no campo político, foi marcada, sobretudo, por uma movimentação a que devemos dar um especial relevo, pois ela marca, de forma eloquentemente clara, a posição que a "Academia" tinha em relaçōes à sua "Universidade". Trata-se do caso do Reitor Domingos Fezas Vital, da Faculdade de Direito.

Havia ele assumido a reitoria em 15 de Março de 1927, devido ao pedido de demissão de Almeida Ribeiro. Ocupava assim o cargo, passando da condição de Vice-Reitor a Reitor, nos termos da lei. Monárquico, homem de confiança da Ditadura e vítima, com Salazar, Carneiro Pacheco e Magalhães Colaço, do famoso processo de suspensão de 1919 por alegadas posiçōes contra-revolucionárias em relação à República(37), não the foi negado o desempenho de funções quando, por alteração legal ocorrida em 1928 e confirmada em 1929(38), O Reitor passou a ser de livre escolha do

(37). Cfr. J. Ferreira Gomes. A Universidade de Coimbro duronte a Primeira Repúblico. pp. 317 ss.. e o artigo de António Pedro Vicente. "Conflitos académicos durante a I ". República. Professores acusados de ofensas às instituiçōes democráticas". in Universidode(s). Histório. memório, perspectivos, Coimbra, 1991, vol. 5. p. 327 s5.

(38). Através do decreto $n^{\circ} .15453$, de 10 de Maıo de 1928, "as nomeaçōes para o cargo de reitor passam a ser de livre escolha do Governo". Pelo decreto $n^{\circ} .16623$, de 18 de Março de 1929. art. $2^{\circ}$. é modificado o art. $5^{\circ}$. do já citado Estatuto da Instrução 
Governo. Pediu a exoneração, em 10 de julho de 1928, que Ihe foi recusada pelo Ministro da Instrução Pública( ${ }^{(39)}$.

O conflito que opôs os estudantes republicanos a Fezas Vital terá resultado de dois motivos: um deles, o principal, foi provocado pela eleição do representante dos estudantes ao Senado, em fins de 1928, do monárquico Bento Caldas, preterindo o académico republicano Vitorino Nemésio. Os republicanos entenderam ter havido ilegalidade no processo eleitoral, que fora presidido pelo próprio Reitor, razão pela qual impugnaram as eleições, acabando por thes ser dada razão pelo Supremo Conselho de Administração Pública, após indeferimento inicial do Ministro da Instrução(40). Outro motivo detectámo-lo no jornal do C.R.A., Gente Nova, o qual dá conta da polémica levantada por um manifesto em que se acusava o Reitor de ter afastado, do concurso para Secretário Geral da Universidade, Rui Machado, pelo facto de ele ser republicano(41).

Gerou-se, assim, um movimento de contestação ao Reitor, só comparável ao que sucedeu no século XIX com o célebre revolta contra o reitor Basilio Alberto de Sousa Pinto, liderada pela Sociedade do Raio e por Antero de Quental. Surgiram panfletos agressivos contra ele, contra os "integralistas" e contra a Universidade e. entre outros actos, foi boicotada a abertura solene das aulas, em Outubro de 1930, na qual proferia a "oração de sapiência" o Professor da Faculdade de Direito Mário de Figueiredo, que seria uma das figuras mais ligadas ao regime salazarista.

Dissemos que este conflito é particularmente significativo pela oposição que nele se estabelece entre a "Academia", ou pelo menos o seu sector mais militante e agressivo, e a "Universidade". Vamos explicar

Universitária (decreto $n^{\circ} .12$ 426, de 9 de Maio de 1926), passando a vigorar o seguinte:

106 "O Reitor será livremente escolhido pelo Governo entre os professores do ensino superior ou Juizes de Relação e Supremo Tribunal de Justiça".

(39). Cfr. Francisco Morais, Reitores do Universidade de Coimbra, pp. 117-118, e Manuel Augusto Rodrigues, A Universidade de Coimbra e os seus Reitores, pp. 338 ss. Mais desenvolvida investigação sobre os vários aspectos deste reitorado foi realizada por Ana Maria Mendes, em trabalho não publicado. Sobre Fezas Vital, cfr. Reitores da Universidade de Coimbro. 1927. 1960. Trabalho de fim de curso policopiado. Coimbra, 1992, pp. 9 ss.

(40). Depoimento de M. Cal Brandão, in ob. cit., pp. 164-165 e 168-169.

(41). Cfr. Gente Nova, $n^{\circ}$. 13, 18.3.1928, "O Senhor Reitor e a Academia". 
a razão da nossa afirmação que é particularmente evidente através da leitura do panfleto intitulado Delenda est Carthago. A Academia Republicana perante a Universidade de Coimbra ${ }^{42}$ ).

O texto, de uma violência sem quartel, apresenta da Universidade uma imagem tenebrosa, nomeadamente de quase todos os professores das Faculdades de Letras e de Direito. A razão disso é, de resto, facilmente compreensivel, por serem as duas faculdades que foram consideradas durante a República como reduto do conservadorismo e da reacção monárquica, pelo que foram vítimas de processos por parte do regime deposto em 28 de Maio de 1926, no caso da Faculdade de Letras através da sua supressão pelo governo de Leonardo Coimbra(43), que (como dissemos) não chegou a concretizar-se e, no caso da Faculdade de Direito. pela acção contra os quatro lentes já várias vezes referida.

Desta forma, estabelecia-se uma distinção entre a "Universidade" e a "Academia", que no entanto vinha a ser atenuada - e isso não deixa também de ser sintomático - quando, após o pedido de demissão de Fezas Vital, apresentado formalmente por razões corporativas e não devido à contestação estudanti ${ }^{(44)}$, assumiu o lugar de forma interina oVice-Reitor Prof. Luís Carriço, da Faculdade de Ciências, até que o governo, exercendo o seu poder, nomeou também interinamente, para pacificar a Academia, Pedro Amor Monteiro de Barros, coronel do Exército, professor do Instituto SuperiorTécnico de Lisboa e Director-Geral do Ensino Superior e das Belas Artes. Unanimemente

(42). Delenda-est Corthago. A Academia Republicona perante a Universidade de Coimbro. Coimbra, 1930. Vide a sua transcrição in Os estudantes no regime fascisto, p. 179 ss.

(43). Cfr. decreto $n^{\circ} .5770$, de 10 de Maio de 1919: desanexa a Faculdade de Letras de Coimbra, que acusa de uma "quase completa orientação tomista de forma escolástica". e coloca-a na Universidade do Porto.

(44). Cfr. Actos do Senado, sessão de 24 de Dezembro de 1930. fls, 41 ss. As razōes invocadas eram. na verdade, as leis que, segundo o Reitor, "afectaram ou pretenderam afectar profundamente, quer a organização dos serviços. quer o património", entre as quais estava a extinção da Escola Superior de Educação e a reforma muito contestada da Faculdade de Ciências. É curioso que, nesta sessão do Senado, o professor da Faculdade de Medicina. Lúcio de Almeida, que se manifestou como adversário do regime, propôs uma moção pela qual se protestasse "contra os actos ministeriais que provocaram esta demissão", considerando esta posição crítica. no contexto da discussão que se gerou, como "uma atitude de profilaxia social". Sintomaticamente, foi nisso logo contrariado pelos professores afectos ao sistema, Mário de Figueiredo e Ferrand de Almeida. 
considerado como amigo dos estudantes, sobretudo pelos estudantes republicanos, o Doutor Luís Carriço foi cognominado carinhosamente como o "Reitor da Academia"(45).

A "Universidade" era, porém, considerada como uma instituição decadente, sendo particularmente contestada pelos sectores mais avançados, isto é, pelos republicanos, de tendências mais moderadas ou mais radicais. A questão que se verifica em 1933, já na vigência do Estado Novo, motivada por um documento assinado pela grande maioria dos professores de Coimbra ${ }^{(46)}$, é a prova de que, na realidade, qualquer pretexto serviria para que sobre ela recaissem críticas violentas.

Numa mensagem dirigida ao Ministro da Instrução Pública, justificase a falta de qualidade do ensino universitário basicamente pela falta de autonomia da corporação e pelas carências de condições de trabaiho dos seus professores. Assim, as reformas requeridas focavam em particular a melhoria das condições dos docentes, inclusivamente no domínio dos vencimentos. Este documento, escrito em tom equilibrado - apesar de uma ou outra expressão infeliz, que feriu a sensibilidade republicana ${ }^{(47)}$ - foi assinado por cinquenta e quatro professores, isto é, pela grande maioria do quadro docente da Universidade, entre os quais se encontravam alguns assumidos democratas, como Anselmo Ferraz de Carvalho, da Faculdade de Ciências, ou Mário Silva. Conforme vieram a proclamar os folhetos de crítica que tal mensagem originou, só não terá sido assinado por três professores catedráticos, ou seja, Joaquim de

(45). Cfr. o referido depoimento de M. Cal Brandão, in ob. cit. pp. 170-171. e A. Macedo. Da Acodemı do meu tempo aos estudantes de amanhā, Porto, 1945, pp. 24-29. Ver também alguns pormenores destas lutas em Alberto Vilaça, Para a história remoto do PCP em Coimbro. 1921-1946, Lisboa. Caminho, 1997, p. 63 ss.

(46). Cfr. "Uma mensagem do corpo docente da Universidade de Coimbra ao sr. ministro da Instrução", in Novidodes, 18 de Agosto de 1933.

(47). Nomeadamente chocou, com compreensivel razão, a sensibilidade dos críticos o passo em que, para salientarem as suas más condiçōes de trabalho - as quais os obrigavam a dar muitas aulas sem terem tempo para se dedicar à investigação - os professores de Coimbra comparavam a sua situação "ao papel humilhante de mestre-escola" (jornol cit, p. 4. coluna I). 
Carvalho e Virgílio Correia (ambos da Faculdade de Letras) e Aurélio Quintanilha (da Faculdade de Ciências) ${ }^{(48)}$.

Vários artigos de jornais e panfletos surgiram, pois, no contexto desta reivindicação do corpo docente universitário. Nomeadamente a contestação ao documento foi liderada pelo grupo "Renovação Democrática", saído da "Seara Nova". António Lobo Vilela, que havia frequentado a Faculdade de Ciências, foi um dos plumitivos desta questão. Após ter escrito antes dela alguns artigos no jornal A Voz do Justiço, da Figueira da Foz, periódico em que, de resto, se realizara um "Inquérito sobre a Universidade". e de ter publicado um opúsculo significativamente intitulado A crise da Universidade ${ }^{(49)}$, redigiu, já depois de ser conhecida a mensagem dos lentes de Coimbra, o pequeno livro A Universidade folou!...(50).

As suas ideias revelaram um pensamento básico que se radicava nas concepções mais extremistas da Convenção, por altura da Revolução Francesa: manifesta-se contra a "autonomia", corporativa ou liberal, da Universidade, e defende a sua extinção.

Mas o certo é que não eram só estudantes ou ex-estudantes a contestar a Universidade ou a criticar o seu modo de funcionamento. Assim o fizeram explicitamente, antes desta polémica, Rodrigues Lapa, professor da Faculdade de Letras da Universidade de Lisboa, e Aurélio Quintanilha, Professor da Faculdade de Ciências de Coimbra, em conferências organizadas pelo jornal O Século, na capital${ }^{51}$.

(48). Cfr. a referência a esses nomes nos folhetos, a que a seguir nos vamos referir: A Lôbo Vilela, A Universidade falou!.... Figueira da Foz, Cademos de Cultura Democratista, 1933. p. 12, nt, e Eduardo Salgueiro, O suicídio dos catedráticos de Coimbra, Figueira da Foz. Cadernos de Cultura Democratista, 1933. p. 14. Qualquer dos folhetos fala de "professores catedráticos". Portanto, nesta perspectiva, a informação deve estar correcta. No entanto, o documento não é apresentado em nome dos "professores catedráticos" e sim em nome de "um grupo de professores da Universidade de Coimbra". Assim. poderemos dizer que falta também, pelo menos, o nome de Silvio Limá, que. não sendo professor catedrático, era então doutor e tinha a categoria de "professor auxiliar". Desconhecemos se a sua falta tem algum significado.

(49). A crise da Universidade, Cadernos de Cultura Democratista, Figueira da Foz, 1933.

(50). Ob. cit.

(51). Cfr. Rodrigues Lapa, "A politica do idioma e as nossas Universidades", in O Século, 16 de Fevereiro de 1933, e A. Quintanilha, "O papel da investigaçāo cientifica e as suas necessidades em Portugal". in O Século. 26 de Março de 1933. 
Se a conferência de Rodrigues Lapa provocou reacçōes na Universidade de Coimbra, sem todavia assumirem o carácter formal de um protesto, pois o seu autor era professor em Lisboa, mais graves foram, obviamente, as reacções à palestra de Quintanilha. Uma afirmação do professor de Ciências feriu particularmente a sensibilidade de alguns professores: "A Universidade não produz porque a investigação científica não tem tradições entre nós, porque o recrutamento dos elementos novos é feito pelos velhos, que seleccionam à sua imagem e semelhança, pessoas com a mesma mentalidade e que não sejam elementos perturbadores".

Alguns membros do Senado e da Assembleia Geral da Universidade ${ }^{(52)}$ moveram uma dura luta a Aurélio Quintanilha, tendo sido aprovada no primeiro órgão uma moção contra ele. Lideraram o processo Fazes Vital, exreitor e director da Faculdade de Direito, vítima, como se disse, do processo de 1919, por alegadas acçōes contra-revolucionárias, situação que de resto invocará com orgulho na Assembleia Geral da Universidade, e da contestação dos estudantes em 1930, e Mário de Figueiredo, amigo íntimo de Salazar e um dos mais indefectiveis apoiantes do Estado Novo. No Senado e na Assembleia, Fezas Vital foi quem introduziu a questão, apresentando, como director da sua Faculdade, uma moção contra o comportamento de Quintanilha, e discursando ali e na Assembleia da Universidade durante largo tempo sobre a situação em termos bem duros. No entanto, apesar do apoio de alguns colegas, entre os quais se deve destacar o Professor Eusébio Tamagnini, nacional-sindicalista e que virá a ser Ministro da Instrução Pública de Salazar (1934-1936), a posição de Fezas Vital e de Mário de Figueiredo foi invertida, não tanto devido ao discurso de Aurélio Quintanilha, que acendeu um debate pessoal exaltado, mas sobretudo devido às posições assumidas por Ferraz de Carvalho, secundadas por Joaquim de Carvalho e. indirectamente, por uma moção dos estudantes. Foram elas que levaram a Assembleia a votar uma moção, que o próprio Mário de Figueiredo assinou. pela qual não só se dava "o incidente por liquidado". mas também se

(52). Cfr. Arquivo da Universidade de Coimbra, Actas do Senado, sessões de 3.9 e 27 de Abril de 1933, e A Universidade de Coimbra no século XX. Actos do Assembleia Geral, Coimbra. Arquivo da Universidade. sessão de 6 de Maio de 1933. 
promoveria "uma larga discussão do recrutamento do professorado universitário, no campo elevado dos princípios" e se reivindicaria "o estudo de todas as questōes pedagógicas da organização universitária".

Foi esse "estudo" decerto que levou à produçāo, meses depois, do referido abaixo-assinado dirigido ao Ministro da Instrução Pública, o tal que foi considerado pelos críticos um documento infeliz. $O$ suicídio dos catedráticos, chamou um militante do movimento da "Renovação Democrática" à mensagem dos cinquenta e quatro lentes de Coimbra...(53)

\section{O fim do "problema universitário" e a extinção da Imprensa da}

\section{Universidade}

la, porém, terminar, praticamente, este debate sobre o ensino universitário - assim como sobre os destinos da política portuguesa -. que envolvia estudantes, antigos estudantes, professores e simples cidadāos, debate que se verificou no domínio dos textos e nos órgãos da Universidade, mas também (como vimos) nas manifestações de rua, em conferências e em comícios ou em reuniões secretas. E se se deu em Coimbra (universidade onde particularmente o estudámos), ter-se-á dado com fulgor idêntico, ou ainda maior - a aceitar as críticas dirigidas sobretudo a Coimbra pelos ideólogos de "esquerda" e os testemunhos dos ideólogos de "direita" - no Porto e em Lisboa ${ }^{(54)}$. Aliás, são conhecidos alguns episódios de grande violência que se verificaram nesses

(53). Cfr. Eduardo Salgueiro, ob. cit.

(54). É sintomático o testemunho do folheto a que a seguir nos vamos referir, $O$ problemo universitório em Portugol, quando defende a Universidade de Coimbra das críticas que the eram fertas, nomeadamente pelo movimento de "Renovação Democrática". Vejamos este passo significativo: "Sim, $\mathrm{O}$ que os apoquenta é a Universidade de Coimbra. Porque mais trodicional, porque mais nocionol, porque mais científico. a Universidade de Coimbra é o alvo comum das cóleras, das invectivas, dos rancores. dos despeitos, das injúrias... Eles não falam na Universidade do Porto, onde fumegam focos deletérios das mais nefastas ideologias... Também a Universidade de Lisboa é poupada - pelo mesmo motivo. Medram lá, prosperam lá, exemplares característicos da decadência que os ventos do oriente sopram - e por esse motivo, também a Universidade de Lisboa goza de certa impunidade" (pp. 25-26). Aliás. parece indubitável que. por exemplo. uma das razões da tentativa. năo concretizada. de extinguir a 
outros meios universitários ${ }^{(55)}$. Mas, como dizíamos, em breve ia terminar este debate. $E$ quase diríamos que o tom da posição governamental é dado por um texto que vem ainda na sequência da questão universitária de 1933. Trata-se do folheto, publicado em 1934 pela Editorial Vanguarda, intitulado $O$ problema universitário em Portugal.

Defensor de um "nacionalismo totalitarista", o texto, sem autor, afirma com uma grande clareza de princípios:

"Dentro do Estado Novo, não há, e não pode haver duas opiniões: Estado de tendências totalitárias, o Problema universitário terá que subordinar-se, na sua solução, às directrizes ideológicas que inspiram o Estado Novo. A Universidade terá que viver integrada no Estado Novo, e não à margem do Estado, alheia ao Estado, e quando Deus quer, inimiga do Estado. A Universidade, vivendo integrada no Estado, tem que pôr as suas actividades, todas as suas canseiras, ao serviço do Estado, no campo que The é próprio. Dentro da atmosfera do Estado Novo, ela tem que ser nacionalista, e não internacionalista; corporativista, e não liberalista; organicista, e não democrática"(56).

E, depois de ter defendido a Universidade de Coimbra e de atacar o movimento de "Renovação Democrática", de ter afirmado o "totalitarismo" do Estado Novo, que deve integrar as instituições nos seus princípios e de

Faculdade de Direito de Lisboa, em 1928, a que havia pertencido, emblematicamente. Afonso Costa, era exactamente haver nela um importante lote de professores ligados à Primeira República, tais como Barbosa de Magalhães, Rocha Saraiva, Abranches Ferrão, Pedro Martins, Vieira da Rocha. Quanto à Faculdade de Letras do Porto, que foi efectivamente abolida. ela resultara de uma tentativa da República de extinguir a de Coimbra. exactamente pelos motivos contrários - o seu alegado carácter conservador. Nela ensinavam republicanos como Leonardo Coimbra (que havia sido o autor do projecto de extinção da congénere faculdade de Coimbra), Luis Cardim. Newton de Macedo.

(55). Foi o caso de uma grande manifestação ocorrida no Porto em Abril de 1931. de que resultou. devido à queda de um varandim, a morte do estudante joão Martins Branco. Verificou-se então uma grande concentração académica no cortejo fúnebre. Sobre estas manifestações e sobre outras ocorridas em Lisboa, Porto e Coimbra, ver o citado livro Os estudantes no regime fascisto.

(56). O Problemo Universitário em Portugal, Editorial Vanguarda, Avenida da Liberdade. 3 $2^{\circ}$. Lisboa, 1934, pp. 11-12. 
execrar o bolchevismo estudantil, mais frequente em Lisboa e no Porto, termina num apelo retórico de nacionalismo dirigido à juventude, bem ao gosto do fascismo:

"A Mocidade passa uma hora dificil, porque os ventos que sopram e a tentam, são vários e desvairados. Urge empolgá-la, conquistá-la e conduzi-la a destinos gloriosos - quais sejam o de servir incansavelmente e desinteressadamente a sua Pátria, que é a mais bela de todas as Pátrias. escutando assim a palavra formosa do Poeta:
O mocidade heróica e bela,
Morre a cantar!... morre... porque ela Reviveró!" (57)

Como se viu, a Universidade perdera a sua autonomia desde que o reitor não só passara a ser livremente nomeado pelo Governo, mas principalmente na medida em que passara a ser considerado, desde a legislação de 1930, 0 "representante do Ministro da Instrução Pública perante a Universidade"(58). Em 1931, durante o ministério de Gustavo Cordeiro Ramos, previne-se o pessoal docente que "as infracções e delitos cometidos [...] no exercício das suas funções ou, fora deste exercício, em circunstâncias que o afectam serão punidos" com penas que poderiam ir desde a advertência à demissão(59). Porém, não era tudo. Três actos fundamentais, em anos sucessivos, marcam realmente $o$ ataque do governo de Salazar às ideias democráticas, que ainda subsistiam na Universidade, e a sua integração dentro dos esquemas "corporativos orgânicos" do regime:

O primeiro foi a extinção da Imprensa da Universidade, que era dirigida pelo Professor Joaquim de Carvalho(60). É este afinal o caso que mais nos interessa devido à finalidade da nossa análise. Mas, como já se depreendeu,

(57), Ob. cit. p. 38.

(58). Cfr. Estatuto da Instrução Universitária, decreto-lei nº 18717.2 de Agosto de 1930. art. $8^{\circ}$.

(59). Decreto $n^{\circ} .19794,29$ de Maio de 1931

(60). Cfr. o citado Decreto-Lei $n^{\circ} 24$ 124, de 30 Junho de 1934, regulamentado pelo decreto-lei $n^{\circ} 24$ 440, de 29 de Agosto do mesmo ano. Ver sobre o tema Jorge Peixoto. artigo in ob. cit. 
não vamos tecer sobre ele considerações demasiado específicas, por duas ordens de motivos: em primeiro lugar porque as reflexões fundamentais sobre o tema foram já expendidas por jorge Peixoto e em segundo porque - conforme já afirmámos - nos parece mais lógico explicar essa extinção pelos objectivos essenciais do Estado Novo, tendo em conta as perturbações que se verificaram durante a Ditadura Militar e os primeiros anos do regime de Salazar, do que por motivos meramente casuísticos.

Digamos que, sem dúvida, se tratou de um acto de natureza política. Pode justificar-se, basicamente, pela ideologia republicana, sempre afirmada, de Joaquim de Carvalho. cuja acção convinha de alguma forma combater. Se é provável que Salazar e os seus colegas de Governo, alguns dos quais eram originários de Coimbra, tendo assinado, obviamente, o decreto regulamentador da extinção da Imprensa - Manuel Rodrigues Júnior e Caeiro da Mata - . não desejavam, ao contrário do que (como veremos) fizeram com outros professores, atingi-lo "pessoalmente", por certo devido às suas posições em defesa da Faculdade de Letras e da Universidade de Coimbra em 1919, consideraram oportuno tomar uma medida "institucional" que indirectamente atingia Joaquim de Carvalho. Por outro lado, a decisāo justificar-se-ia principalmente - conforme atrás se sugeriu - pela desejo de neutralizar uma instituição anexa à Universidade que, devido à sua prática de autonomia, poderia publicar textos pouco adequados à ideologia única do Estado Novo.

No entanto, analisando as obras publicadas no tempo da administração de Joaquim de Carvalho ${ }^{(61)}$, dificilmente encontramos na actividade editora e impressora da Imprensa universitária alguma linha definida em prol de um ideário democrático assumidamente de oposição ao pensamento salazarista. Quando muito depararemos com uma acção cultural pluralista, onde, a par de obras de alguns republicanos, sobre temas que, em geral, não eram explicitamente de carácter político, se encontram textos de nacionalistas da ala de Salazar ou que vieram a integrar-se no grupo de acção cultural e 114 ideológica do Estado Novo. Antes da Ditadura Militar houve uma colecção da Imprensa da Universidade chamada "Biblioteca Democrática". Foi nela que

(61). Como amostragem de algumas obras publicadas pela Imprensa da Universidade (no tempo de Joaquim de Carvalho e muito antes). ver Imprensa do Universidode. Cotólogo. Câmara Municipal da Figueira da Foz. Serviços Culturais, 1992. 
em 1924 se publicou a obra de Henriques Nogueira Estudos sobre a reforma em Portugal. Mas, essa coleç̧ão foi desactivada, mantendo-se sim colecções aparentemente "inofensivas" como "Subsídios para a História da Arte Portuguesa" e criando-se outra, que já podia ser considerada mais perigosa. intitulada "Filósofos e Moralistas". Nela publicaram-se obras de Benedetto Croce sobre Hegel, numa tradução de Vitorino $\mathrm{Nemésio}^{(62)}$, ou do republicano Newton de Macedo, sobre Psicologia Experimenta|(63). Se, todavia, este livro do professor da Faculdade de Letras do Porto, de fundação republicana, seria "inofensiva" do ponto de vista científico-cultural no âmbito do que se considerava o modelo científico-cultural do jovem Estado Novo (embora seja difícil avaliar o que se entendia ou não por "inofensivo"). já talvez não seja tão "inocente" a obra publicada três anos antes pelo mesmo autor durante a Ditadura Militar, A luta pela liberdade no pensamento europeu ${ }^{(64)}$. Além disso, talvez a última obra a ser editada pela Imprensa (já com data de 1935) tenha sido o livro de Sívio Lima, O Amor Mistico ${ }^{(65)}$ que, na verdade, nunca chegou a vir a público, pois o jovem professor foi então demitido, conforme veremos.

Além deste tipo de obras, publicaram-se, portanto, outras de nítido pendor ideológico de "direita" ou de autores representantes dessa corrente. que se integravam perfeitamente na linha de pensamento salazarista, o que. de resto, provocou a crítica dos correligionários de Joaquim de Carvalho, de acordo com o testemunho memorial de Belisário Pimenta ${ }^{(66)}$. Recordem-se os casos de Alfredo Pimenta. Estudos filosóficos e críticos, de Manuel Anselmo, Soluções críticos, e de João Ameal, No limiar da Idade-Nova.(67). Ao nível da

(62). O que é vivo e o que é morto na filosofio de Hegel. Tradução de Vitorino Nemésio. Coimbra, Imprensa da Universidade, 1933

(63). As novas tendencias da Psicologio Experimental a teoria da forma, Coimbra, Imprensa da Universidade, 1933.

(64). A luta pela liberdade no pensomento europeu, Coimbra, Imprensa da Universidade. 1930.

(65). O Amor Mistico.(Noção e volor de umo experiêncio religioso). Coimbra, Imprensa da Universidade, 1935.

(66). Biblioteca Geral da Universidade de Coimbra, Memórias de Belisário Pimenta. manuscrito 3363, vol. XII, . 22 de Agosto de 1932. p. 338. Ver o trabalho de fim de curso de Ana Caldeira Serrano. Belisório Pimento - Visõo crítico dos alvores do Estado Novo, Coimbra, Faculdade de Letras. 2001.

(67). Alfredo Pimenta. Estudos filosóficos e críticos. Prefácio de Ricardo Jorge. Coimbra. Imprensa da Universidade, 1930; Manuel Anselmo, Soluçōes críticos, Coimbra. Imprensa da 
literatura, se é relativamente abundante a publicação de obras de Antero de Quental, que foram objecto de estudos de referência de Joaquim de Carvalho. ou de estudos sobre os autores da "geração de 70", passíveis de serem lidos pela Intelligentsia de esquerda, não deixa também de ser surpreendente a publicação do poema do Padre Vasco Reis, Romaria, prefaciado por Alfredo Pimenta ${ }^{(68)}$, que, surpreendetemente, foi vencedor ex-aequo, com Mensagem de Fernando Pessoa, do prémio de poesia "Antero de Quental", do Secretariado de Propaganda Nacional.

Segundo nos informa Jorge Peixoto, falou-se de um outro motivo mais imediato para explicar a extinção da Imprensa da Universidade. Trata-se do "boato" então propalado de que o jornal A Verdade, de que se publicaram onze números de Julho de 1933 a Fevereiro de 1934, em Lisboa, Coimbra e Madrid, e que foi dirigido por Armando Cortesão, irmão de Jaime Cortesão - que ali publicou, no número 9 de Janeiro de 1934, o poema de rara virulência contra Salazar, intitulado "Maldição" - havia sido, em certa altura, dado à estampa na Imprensa da Universidade ou com os tipos vindos dali. Jorge Peixoto, embora sem citar dados concretos, limita-se a dizer que nenhuma das hipóteses é verdadeira ${ }^{(69)}$. O que devemos acrescentar, quanto a esta situação, apenas para entendermos que. mais do que motivos específicos, houve razões de prática política que levaram a extinguir a Imprensa e a tomar outras atitudes estratégicas é que, para fazer frente ao jornal $A$ Verdade, de nítido carácter oposicionista, passou a publicar-se, por acção do S.P.N., dirigido por António Ferro, um outro periódico, também intitulado sintomaticamente A Verdode (1933-1939), dirigido pelo jornalista nortenho Costa Brochado, que, assim, iniciou uma significativa carreira política orgânica ao serviço do Estado Novo(70).

Universidade. 1934: João Ameal, No limiar da Idade-Nova, Coimbra, Imprensa da Universidade. 1934.

(68). Vasco Reis, A Romaria, Com uma Carta-Prefácio do Sr. Dr. Alfredo Pimenta, Coimbra, Imprensa da Universidade, 1934.

${ }^{(69)}$. Jorge Peixoto, artigo citado in ob. cit. PP. XLIX.LIII.

(70). Vide a tese de mestrado, já concluida mas ainda não defendida em provas públicas, de Joăo Tiago Caldeira de Sousa, Costa Brochado. Um intelectual orgAnico do regime salozaristo. Coimbra. Faculdade de Letras de Coimbra. 200I. 
Ainda surge uma outra hipótese que vislumbrámos no processo da PIDE de Joaquim de Carvalho. No Cadastro Político n. ${ }^{\circ} 72$, com referência a 24 de Fevereiro de 1928, pode ler-se: "Existem fortes suspeitas de que os panfletos intitulados 'Ao Povo Republicano' e 'Ao Exército Republicano' tivessem sido mandados imprimir pelo epigrafado [Joaquim de Carvalho]". E. com referência a 21 de Março do mesmo ano, afirma-se que se mantinham as suspeitas de que "os últimos panfletos distribuídos nesta cidade [Coimbra], devem ter sido impressos na Imprensa de que o epigrafado é Director, de conivência com o Coronel reformado Bandeira e José Rodrigues da Costa que anda fugido"(71)

Dentro da lógica que nos propusemos seguir, acompanhando o rumo de anteriores páginas já publicadas, falemos, pois, das outras medidas tomadas pelo Estado salazarista em relação à Universidade.

Em 13 de Maio de 1935 foi publicado o Decreto n. 25 317, que abria as portas a grandes depuraçōes políticas. No artigo 1.० podia ler-se: "Os funcionários ou empregados, civis ou militares, que tenham revelado ou revelem espírito de oposição aos princípios fundamentais da Constituição Política, ou não dêem garantia de cooperar na realização dos fins do Estado, serão aposentados ou reformados, se a isso tiverem direito, ou demitidos em caso contrário". Foi no contexto desta legislação que foram demitidos. para além dos Professores Abel Salazar, da Faculdade de Medicina do Porto, e Rodrigues Lapa, da Faculdade de Letras de Lisboa, os Professores Silvio Lima e Aurélio Quintanilha ${ }^{(72)}$, respectivamente da Faculdade de Letras e da Faculdade de Ciências da Universidade de Coimbra. Entre os funcionários

(71). IAN/TT. Arquivo da PIDE/DGS. Joaquim de Carvalho. Processo Individual n. ${ }^{\circ} 646$. doc. $n^{\circ} 123$.

(72). Vide Diório do Governo, n. ${ }^{\circ}$ III.I série, 16.5.1935. e n. ${ }^{\circ} 173.1$ série, 27.7.1935. Sobre os casos de Silvio Lima e Aurélio Quintanilha, ver o estudo de Nídia Gregório, por nós dirigido, "'Subversāo' e repressão na Universidade de Coimbra - dois casos exemplares", in Ideologia, cultura e mentalidade no Estado Novo. Ensaios sobre a Universidade de Coimbro, Coimbra. Faculdade de Letras, 1992, p. 23 ss. Sobre Abel Salazar, vide Norberto Cunha, Génese e Evolução do Ideário de Abel Salazor. Dissertação de doutoramento. Braga, Universidade do Minho, 1989. Vide, também. sobre Silvio Lima, o artigo da nossa autoria "Estado Novo e vigilância policial na Universidade. Os casos de Silvio Lima e Joaquim Ferreira Gomes". in Ensaios em homenagem a jooquim Ferreira Gomes, Lisboa, Núcleo de Análise e Intervençăo Educacional - Faculdade de Psicologia e de Ciências da Educação, 1998, e outro 
destaque-se o Secretário da Universidade José de Oliveira Neves ${ }^{(73)}$, curiosamente genro do reitor de então, João Duarte de Oliveira.

As razōes de tais demissōes são óbvias. Silvio Lima era um militante republicano desde os seus tempos de estudante e distinguira-se, já na qualidade de Professor Auxiliar, no domínio da polémica, em particular através das suas Notos Críticos à obra do Cardeal Cerejeira, A Igreja e o pensamento contemporaneo, crítica essa que provocou grande celeuma nos meios católicos e conservadores ${ }^{(74)}$. A sua posição em defesa da ciência, pondo entre parênteses a fé, contrariava a tese de Cerejeira, que considerara as duas realidades interligadas, opondo-se, assim, ao pensamento laicista liberal, republicano e socialista e esperando o "Renascimento Cristão" dos intelectuais. Aquela teoria "heterodoxa" de Silvio Lima, a juntar à sua dissertação sobre o "Amor Mistico"(75), com que desejava apresentar-se a provas para professor extraordinário nesse ano de 1935, foram, pois. suficientes para precipitar o seu processo de exoneração. Não se poderá esquecer que o Catolicismo fazia parte integrante da ideologia do Salazarismo e da própria estrutura do pensamento universitário coimbrão. Quanto a Aurélio Quintanilha, era conhecida a sua acção republicana, e até

artigo. de próxima a parição, a publicar, no Porto, em volume de homenagem a joão Francisco Marques.

(73). José de Oliveira Neves havia proferido em 1933. na Associação dos Artistas de Coimbra, uma conferência sobre o tema "O Nacional-Sindicalismo e o movimento operário", na qual atacara o fascismo italiano, o nazismo alemāo e o nacional-sindicalismo português, onde militavam professores da Universidade de Coimbra próximos de Salazar, como Eusébio Tamagnini e Cabral Moncada. Cfr. os comentários acerca desta conferência no jornal nacionalsindicalista Revoluçōo. 25.4.1933. Vide uma curta notícia sobre este caso in Nídia Gregório, idem, pp. 34-35, e uma breve referência em Jorge Peixoto. ob. cit. p. XLVI.

(74). Cfr. a obra Notas críticas oo livro do Sr. Cordial Gonçalves Cerejeira "A Igrejo e o 118 Pensamento Contemporôneo", $2^{2}$ edição. corrigida, ampliada e com um apêndice-resposta, Coimbra, Livraria Cunha. 1931. A Iª. edição da obra de Cerejeira, que era então professor da Faculdade de Letras e um militante católico do Centro Académico de Democracia Cristā (C.A.D.C.), data de 1924 e teve depois sucessivas ediçōes. Outra obra que criticou o livro do cardeal foi publicada em Lisboa pelo médico Almeida e Paiva. Liberdode, sciéncio e religiāo. Estudo das bases da crença e vida da Igreja. Seguido duma réplica a propósito de "A Igreja e o pensomento contemporôneo", Lisboa, 1930.

(75). Cfr. ob. cit: O Amor Mistico. (Noçāo e valor de uma experiéncia religiosa), vol. I. Coimbra. Imprensa da Universidade. 1935. 
- seu radicalismo, pois militara enquanto estudante na associação anarquista "Falange Demagógica"(76). A agravar essa situação, precipitou-se o processo originado pela conferência de $O$ Século, que sumariamente descrevemos, 0 que, apesar do apaziguamento corporativo que the sucedeu, criara a ideia de que tomara uma posição ostensiva contra a Universidade tradicional.

Finalmente, dir-se-á que o ano de 1936 é decisivo em termos de política da educação do Salazarismo e da extinção das liberdades académicas que subsistiam.

Carneiro Pacheco, companheiro com Salazar e Fezas Vital (para além de Magalhães Colaço, falecido prematuramente) do célebre processo de 1919, já várias vezes referido, sobe à pasta do Ministério da Instrução Pública, que, pela lei n. ${ }^{\circ}$ । 94I, de II de Abril, se transforma em Ministério da Educação Nacional (Base I). Para além de aspectos de organizaçāo a criação da Junta Nacional de Educação, cuja primeira secção era sintomaticamente a de "Educação moral e física" (Base II) - deve salientar-se que a Base $V$ dizia respeito à "selecção do professorado de qualquer grau de ensino", exigindo-se a "sua essencial cooperação na função educativa e na formação do espírito nacional". E na Base IX apontava-se para a Mocidade Portuguesa, cujo Regulamento surgirá em 4 de Dezembro: "Será dada à mocidade portuguesa uma organização nacional e pré-militar que estimule o desenvolvimento integral da sua capacidade física, a formação do carácter e a devoção à Pátria e a coloque em condições de poder concorrer eficazmente para a sua defesa". É certo que a Mocidade Portuguesa não teve grande efeito ao nivel do ensino superior, mesmo que se considere que $\circ$ grupo dos jovens dos 17 aos 26 anos ("cadetes") constituiria a "Milícia", que colaboraria directamente com a Legião Portuguesa, e apesar de se fundarem residências da M.P. nas cidades universitárias que albergariam sobretudo estudantes do ensino superior. No entanto. também é verdade que neste ano de 1936 se atentaram fortemente contra as liberdades académicas, por se entender que a Academia deveria ser tutelada pelo Estado. Assim, por "ordem de

(76). Veja-se o seu testemunho em entrevista concedida a joão Medina: João Medina, "Entrevista com Aurélio Quintanilha". Clio - Revisto do Centro de História da Universidade de Lisboa, vol, IV. 1982. 
serviço" do Ministro da Educação, de 6 de Novembro, foi suspensa a representação dos estudantes no Senado e na Assembleia Geral da Universidade e, no mesmo mês, foram suspensas as eleições na Associação Académica de Coimbra, tendo sido nomeada a primeira Comissão Administrativa, presidida por João Pedro Miller Guerra. O grupo católico começava, assim, por cooperar com a estratégia do Estado Novo e da "sua Universidade", o que - diga-se - nem sempre sucederá, como mais tarde virá a provar o próprio Miller Guerra, quando, já professor da Faculdade de Medicina de Lisboa e deputado crítico da ala "liberal" do regime marcelista, vier a denunciar a crise da Universidade(77).

Consumava-se assim o processo de ligação da Universidade ao regime, que era acompanhado de leis gerais repressivas, extensivas a todas as instituições e a todos os funcionário públicos. Era o caso do famigerado decreto-lei n. 27 003, de 14 de Setembro de 1936, que obrigava todos os funcionários do Estado a fazer o seguinte juramento:

"Declaro por minha honra que estou integrado na ordem social estabelecida pela Constituição Política de 1933, com activo repúdio do comunismo e de todas as ideias subversivas."

Mas, resta perguntar, para perceber em toda a perspectiva este processo: como reagiu a Universidade a estas medidas atentatórias da sua liberdade?

Quanto à extinção da Imprensa, não há nenhuma reacção firme por parte do Senado nem por parte da Assembleia da Universidade, que não se reuniu sequer para discutir o assunto. Não há mesmo unanimidade quanto à importância por ela desempenhada na vida universitária, nem quanto a qualquer crítica à medida governamental, nem até quanto a uma moção de apreço ao Ministro da Instrução, Alexandre Alberto de Sousa Pinto, que entretanto se demitira, alegando-se que tal posiçāo poderia ser entendida implicitamente como uma censura ao governo, na medida em que circulavam rumores que ligavam essa demissão à decisão de abolir a

(77). Cfr. As universidades tradicionais e a sociedade moderna. Aviso prévio efectuado na Assembleia Nacional em 14 de Abril de 1970 seguido de debate. Lisboa. Moraes Editores, 1970. 
Imprensa. Acima de tudo, o que se manifesta, para além de uma platónica afirmação de apreço pelo papel desempenhado por Joaquim de Carvalho e da perplexidade de o Reitor não ter tido conhecimento prévio da referida medida, é o cuidado em assegurar que o edifício onde a Imprensa se encontrava se mantivesse na posse da Universidade e que se não extinguisse a acção editorial que a Imprensa vinha assegurando(78). E não deixa ainda de ser curioso - como já o notou Jorge Peixoto(79) - que. na segunda sessão em que $\circ$ assunto foi tratado. Mário de Figueiredo tenha procurado desviar a atenção dos senadores para um assunto que considerou ser mais importante, as obras da Cidade Universitária, em que o edifício da Imprensa se integraria, as quais o governo iria em breve iniciar. Sintomaticamente o Senado fica-se por meras discussões de circunstância, respeitando afinal de contas o decreto-lei do governo presidido por Salazar, que passará sempre a estar presente no espírito da maioria dos professores de Coimbra.

A reacção negativa à extinção da Imprensa veio sim de outros sectores. Por exemplo, uma das personalidades que publicamente manifestou o seu desacordo encontrava-se em posição política bem diferente do ex-director da Imprensa - Alfredo Pimenta ${ }^{(80)}$. Por sua vez, os estudantes, logo em Janeiro de 1935, reuniram uma Assembleia Geral para promover uma homenagem a Joaquim de Carvalho(81).

Quanto à demissão de Sílvio Lima e Aurélio Quintanilha, não se fez mais do que lamentar o sucedido. Somente Anselmo Ferraz de Carvalho propôs que fosse dado provimento ao pedido de inquérito à sua actividade, que Quintanilha havia solicitado para ser realizado, o que todavia não obteve acordo. A expressão mais eloquente será, porém, a de Mário de Figueiredo. Afirmando não poder discutir medidas de legislação geral, não deixou de lamentar as situações: quanto a Sívio Lima, lastimou-a em todos os sentidos, ao passo que, relativamente a Quintanilha, embora lamentasse a sua situação no plano pessoal e no

(78). A.U.C.. Actos do Senodo, sessão de 30 de Junho de 1934. fi. 161 s5, e 30 de Outubro de 1934, fl. 168.

(79), Ob. cit. pp. XLV-XLVI..

(BO). Vide Diório de Notícios. 8 de Setembro de 1934.

(81). Cfr. A. J. Soares, Saudades de Coimbra, Jan. 1935. 
plano universitário, devido à sua competência como investigador, não se solidarizava tanto com ele na qualidade de elemento da corporação universitária, dada a falta de espírito de corpo que havia revelado. A corporação universitária manifestava-se. pois, por omissão, solidária com - Governo, segregando aqueles que se opunham ao espírito de unidade de pensamento para que irremediavelmente $\circ$ regime apontava. Considerando, por outro lado, que o assunto só se deveria debater no interior da corporação, o Senado recusou-se afinal a discutir as decisōes governamentais, tendo, de resto, $\circ$ Reitor afirmado que $\circ$ Ministro the havia garantido tratar-se de "uma medida de ordem geral que não visava as Universidades". Estava, pois salvaguardada a "dignidade da corporação"...82)

Finalmente, o Senado nunca apreciou, de qualquer forma, as medidas governativas relativamente à cessação das liberdades e dos direitos de representação dos estudantes. Nem mesmo a Academia terá tomado quaisquer medidas significativas. Os tempos eram outros - eram momentos de afirmação autoritarista, nacionalista e anticomunista, coincidentes com o avanço franquista na Espanha e com os primeiros sintomas de investidas imperialistas nazis e fascistas. A Universidade e a Academia, salvo em alguns casos pessoais e excepcionais, coincidirão durante alguns anos com o pensamento e a aç̧ão do Estado Novo.

\section{Nota final}

Portanto, procurámos mostrar, através de uma análise alargada, retomando palavras já escritas anteriormente. que apenas foram actualizadas e complementadas, que a extinção da Imprensa da Universidade não é um acto isolado do Estado de Salazar. Ele insere-se

122 numa prática de intervenção - de "tendências totalitárias", para empregar o conceito de uma obra de regime atrás citada - no sentido de controlar ou de neutralizar instituições e pessoas que eventualmente poderiam quebrar a lógica unitária do regime.

(82). Cfr. A.U.C., Actos do Senodo, sessão de 18 de julho de 1935, fls. 190-192. 
Joaquim de Carvalho permaneceu na Universidade, mantendo a disciplina possivel, ao mesmo tempo que manifestava a sua ira contra os regimes autoritários e totalitários. No ano de 1931 - segundo os documentos do Arquivo da PIDE/DGS - fez parte da Comissão Municipal da Coligação Republicana-Socialista, organizada para combater a Ditadura nas eleições ${ }^{(83)}$. Em 1933, reflecte no jornal de Lisboa Diário Liberal em relação a questões políticas que não deixam dúvidas quanto às suas posições ideológicas ${ }^{(84)}$. No mesmo ano participa na publicação das obras de António José de Almeida, escrevendo o prefácio ao volume $\|^{(85)}$. Mas, após a extinção da Imprensa da Universidade, só depois do fim da guerra, nomeadamente em 1949, ano da candidatura à Presidência da República do General Norton de Matos, começou a tomar parte sistematicamente nas actividades da oposição( ${ }^{(86)}$. E, intimamente, nas suas notas pessoais (publicação póstuma do seu filho Joaquim Montezuma de (arvalho), ia exprimindo todo o seu ódio ao regime e ao seu líder, apelidando, por exemplo, o Salazarismo de "nacional-seminarismo" (87).

Entretanto, ia publicando os seus textos científicos e documentos, entre os quais as Notícias Cronológicos da Universidade de Coimbra. segunda edição

(83). Arquivo da PIDE/DGS, Processo Individual n. 646 , Cadastro Político n. ${ }^{\circ} 72$, doc. 123.

(84). Entre outros artigos citados por Jorge Peixoto (ob. cit. pp. XXVIII, nota), vide "Sobre a ideia de estado total. I - Noção de partido político", in jornal cit., 31 de Maio de 1933, "II - Digressão sobre a alma burguesa", idem, 5 de Junho de 1933, e "III - Outra digressão sobre o senhorio do e a civilizaçāo", idem, II de Junho de 1933.

(85). Vide António José de Almeida, Quarenta anos de vida literório e política, 4 volumes, Lisboa, 1933. Os prefácios aos outros volumes foram escritos por Caetano Gonçalves e por Hernâni Cidade.

(86). Cfr. vários documentos no citado Processo Individual n. 646 do Arquivo da PIDE/ DGS. Nomeadamente, no oficio do Inspector-Adjunto José Barreto Saccchetti para o Inspector Superior da PIDE, datado de 31 de Outubro de 1956, pode ler-se: "São bem conhecidas a ideologia e actividades políticas do Professor Joaquim de Carvalho, antisituacionista de ideias demo-maçónicas. Desde 1928 sempre se tem mantido, mais ou menos veladamente, em actividade a favor da chamada 'oposição'. Porém, ultimamente já não procura ocultar a sua verdadeira posiçāo política e a partir de 1949 o nome do Dr. Joaquim de Carvalho aparece em várias comissōes de honra ou organizadoras de todas as homenagens que, em Coimbra ou na Figueira da Foz, têm sido levadas a efeito pela facçāo democrática" (doc. 93).

(87). Vide Mar Alto, Figueira da Foz, n. ${ }^{\circ} \mathrm{s} 403$ a 406, de 8, 15, 22, e 29 de Maio de 1974. 
da obra do século XVIII, da autoria do membro da Academia Real da História Francisco Leitão Ferreira. A publicação data de 1937, ano em que a Universidade celebrava os quatro séculos da sua transferência para Coimbra. E, curiosamente, a obra é publicada "Por ordem da Universidade" ${ }^{\prime(88)}$, assim como o serão muitos outros textos, publicados ao longo do tempo que se Ihe segue. Era como se a Universidade tivesse recuperado, segundo a lógica oficial, a sua capacidade editora. De algum modo, salvavam-se as aparências...

(88). Francisco Leitão Ferreira. Noticias chronologicos da Universidade de Coimbra escriptos pelo beneficiado... 2.a edição organizada por joaquim de Carvalho. Coimbra, Por ordem da Universidade. 1937. 
Srife

investisacaio

Imprensa da Universidade

2001 